\title{
ANALISIS KETERAMPILAN BERPIKIR KRITIS PADA INDIKATOR MEMBERIKAN PENJELASAN LEBIH LANJUT MATERI HIDROKARBON
}

\author{
Herunata $^{1}$, Reza Rewindi Amayliadevi ${ }^{1}$, Hayuni Retno Widarti ${ }^{1}$ \\ 1. Jurusan Kimia FMIPA Universitas Negeri Malang
}

\begin{abstract}
Abstrak - Penelitian ini dilakukan untuk mengukur tingkat keterampilan berpikir kritis pada indikator memberikan penjelasan lebih lanjut yang dimiliki siswa kelas XI MIA tahun ajaran 2018/2019 pada materi hidrokarbon. Rancangan penelitian yang digunakan pada penelitian adalah rancangan penelitian kuantitatif deskriptif. Sumber data yang dianalisis adalah data hasil tes tulis 133 siswa dalam menjawab soal instrumen penilaian keterampilan berpikir kritis yang telah dikembangkan oleh Rodliyah (2018). Aspek keterampilan berpikir kritis pada indikator memberikan penjelasan lebih lanjut terdiri dari lima soal pilihan ganda beralasan. Data yang dianalisis merupakan jawaban siswa yang mendapat skor 1 dalam menjawab soal pilihan ganda beralasan, lalu dikategorikan berdasarkan jumlah persentase menurut Karim (2015). Hasil penelitian menunjukkan bahwa siswa memilliki keterampilan berpikir kritis dengan indikator memberikan penjelasan lebih lanjut pada materi hidrokarbon yaitu a) 57,90\% pada pokok bahasan isomer senyawa (kategori rendah), b) 67,67\% pada pokok bahasan kegunaan senyawa hidrokarbon (kategori cukup), c) 89,47\% pada pokok bahasan sifat fisika dan sifat kimia senyawa hidrokarbon : sifat fisika senyawa hidrokarbon (kategori sangat tinggi), d) 55,64\% pada pokok bahasan sifat fisika dan sifat kimia senyawa hidrokarbon : reaksi pembakaran senyawa hidrokarbon (kategori rendah), dan e) 11,28\% pada pokok bahasan tata nama senyawa hidrokarbon (kategori sangat rendah).
\end{abstract}

Kata kunci: keterampilan berpikir kritis, indikator memberikan penjelasan lebih lanjut, materi bidrokarbon

\begin{abstract}
The purpose of this research measured the ability of critical thinking skills on hydrocarbon topic with focused on the further-explanation-indicators in 11th MIA grade students 2018/2019 academic year. This research used a descriptive quantitative research design. The data was analyzed came from 133 students test results in answering questions of critical thinking skills instrument what developed by Rodliyah (2018). The aspect of critical thinking skills with the further-explanation-indicators consisting of five reasoned multiple choice questions. Analyzing were done from students's answering whose 1 scored, then categorized by percentage according to Karim (2015). The results showed that students had critical thinking skills with the further-explanation-indicators on hydrocarbon topic including a) $57,90 \%$ on the subject of isomeric hydrocarbon compounds (low category), b) 67,67\% on the subject of the use of hydrocarbon compounds (average category), c) $89,47 \%$ on the subject of the physical and chemical properties of hydrocarbon compounds : the physical properties of hydrocarbon compounds (very high category), d) 55,64\% on the subject of the physical and chemical properties of hydrocarbon compounds : combustion reaction of hydrocarbon compounds (low category), and e) 11,28\% on the subject of nomenclature of hydrocarbon compounds (very low category)..
\end{abstract}

Keywords: critical thinking skills, further explanation indicators, bydrocarbon topic

\footnotetext{
${ }^{1}$ Corresponding author: Jurusan Kimia, Fakultas Matematika dan Ilmu Pengetahuan Alam, Universitas Negeri Malang. Email: herunata.fmipa@um.ac.id
} 


\section{PENDAHULUAN}

Tuntutan perubahan yang esensial di abad ke-21 ini adalah menciptakan sumber daya manusia yang berkualitas. Sumber daya manusia itu diharapkan memiliki kemampuan untuk membangun tatanan social-ekonomi, dan sadar akan pendidikan nasional (Santika dkk, 2018). Terlebih lagi, ekonomi abad ke-21 telah bergeser menjadi ekonomi layanan. Pergeseran ini disebabkan oleh perkembangan informasi, pengetahuan, dan inovasi. Pergeseran ekonomi menyebabkan semua negara bersaing secara global (Puspita dkk, 2017). Seiring dengan adanya perkembangan zaman dan teknologi baik di bidang informasi maupun komunikasi berdampak pada sistem pendidikan. Sistem pendidikan dituntut untuk mampu meningkatkan kualitas pendidikan berkarakter guna mempersiapkan sumber daya manusia yang berkompeten untuk menghadapi abad ke-21. Pada abad ke-21 semua negara bersaing secara global dalam berbagai bidang. Akan tetapi, hasil tes pada siswa-siswa di Indonesia oleh Programme for International Student Assessment (PISA) tahun 2015 menunjukkan bahwa pada bidang sains Indonesia berada di peringkat kesembilan paling akhir dengan hasil nilai rata-rata PISA 2015 yaitu 403, sedangkan pada bidang membaca berada pada peringkat ketujuh dengan hasil nilai rata-rata yaitu 397 (OECD, PISA 2015 Database). Hal ini menunjukkan perlunya dengan segera untuk Indonesia meningkatkan kemampuan sains siswa di lingkup global. Salah satu upaya meningkatkan kualitas pendidikan di Indonesia adalah menerapkan Kurikulum 2013. Penerapan Kurikulum 2013 ini bertujuan untuk meningkatkan potensi dan keterampilan berpikir siswa di abad ke-21.

Kartimi (2012) mengemukakan bahwa upaya peningkatan mutu sumber daya manusia Indonesia ini dapat dilakukan diantaranya melalui pendidikan sains. Sains yang sarat akan kegiatan berpikir dapat menjadi wahana untuk meningkatkan kualitas sumber daya manusia di Indonesia, terutama dalam membangun keterampilan berpikirnya. Salah satu keterampilan berpikir yang harus dimiliki oleh siswa sebagai salah satu sumber daya manusia yang dimiliki oleh Indonesia adalah keterampilan berpikir kritis. Hal tersebut didukung oleh Partnership for 21st Century Skills yang menegaskan bahwa salah satu kecakapan hidup yang harus dimiliki siswa pada abad 21 adalah kecakapan berpikir kritis (Lai, 2011).

Berpikir kritis merupakan kecakapan bernalar dan berpikir reflektif yang berpusat untuk memutuskan hal-hal apa yang meyakinkan untuk dipercaya atau dilakukan (Ennis, 2011). Berpikir kritis merupakan salah satu aspek yang sangat perlu diajarkan kepada siswa karena menurut Arends (2012) berpikir kritis adalah salah satu macam pemikiran pokok yang memerlukan penggunaan proses kognitif berupa analitis dan evaluatif yang terdiri dari menganalisis suatu argumen berdasarkan konsistensi yang masuk akal guna mengetahui simpangan dan penalaran yang salah. Berpikir merupakan salah satu kegiatan yang mencakup banyak aktivitas mental yang bertujuan untuk memahami sesuatu atau mencari solusi untuk menyelesaikan suatu masalah.

Keterampilan berpikir kritis dapat dikembangkan dan dilatih melalui beragam bidang studi, salah satunya adalah bidang studi kimia. Bidang studi kimia merupakan salah satu bidang sains yang mempelajari atom dan molekul beserta sifat-sifatnya. Salah satu materi pada bidang studi kimia adalah materi hidrokarbon. Menurut Ennis (2011), indikator keterampilan berpikir kritis mencakup memberikan penjelasan sederhana, membangun keterampilan dasar, mengemukakan kesimpulan/inferensi, memberikan penjelasan lebih lanjut, memperkirakan dan mengintegrasikan. Materi hidrokarbon memuat banyak pokok bahasan yang relevan dengan keterampilan berpikir kritis berdasarkan indikator yang telah dikemukakan oleh Ennis (2011).

Keterampilan berpikir kritis pada materi hidrokarbon dapat dikembangkan dengan adanya permasalahan kontekstual dalam kehidupan sehari-hari yang digunakan sebagai stimulus agar siswa mampu memiliki alur berpikir yang kritis. Siswa yang masih memiliki alur penalaran atau pemikiran yang masih salah dapat menyebabkan timbulnya kesulitan-kesulitan yang akan dihadapi di kelaskelas berikutnya apabila tidak diperbaiki (Bao dkk, 2002). Keterampilan berpikir kritis siswa berhubungan dengan alur berpikir siswa terhadap penyelesaian soal-soal tes atau permasalahan. 
Jika siswa memiliki konsep awal yang salah maka siswa akan kesulitan mengaplikasikan konsep tersebut dengan konsep lain yang saling berhubungan. Oleh karena itu, diperlukan adanya identifikasi dan analisis untuk mengetahui tingkat keterampilan berpikir kritis yang dimiliki oleh siswa. Pengukuran merupakan faktor penting dalam pendidikan karena melalui pengukuran akan diketahui secara persis dimana posisi siswa pada suatu saat atau pada suatu kegiatan (Kartimi, 2012).

\section{METODE}

Rancangan penelitian yang digunakan pada penelitian adalah rancangan penelitian kuantitatif deskriptif. Penelitian ini dilakukan untuk mengukur kemampuan keterampilan berpikir kritis pada indikator memberikan penjelasan lebih lanjut yang dimiliki siswa kelas XI MIA tahun ajaran 2018/2019 pada materi hidrokarbon di salah satu SMAN di Kabupaten Malang. Subjek penelitian yang digunakan pada penelitian berjumlah 133 siswa sampel yang memiliki kriteria yaitu siswa dalam kelas tersebut telah memperoleh pembelajaran materi hidrokarbon pada semester ganjil tahun ajaran 2018/2019 yang dibelajarkan oleh guru kimia masing-masing.

Pengumpulan data dilakukan dengan cara melakukan tes tulis pada kelas sampel terkait materi yang digunakan yaitu materi hidrokarbon dengan menggunakan instrumen penilaian keterampilan berpikir kritis. Instrumen tes yang digunakan telah dikembangkan oleh Rodliyah (2018) yang mendapatkan kategori sangat layak digunakan karena telah valid dan reliabel. Instrumen penilaian terdiri dari 25 butir soal pilihan ganda beralasan yaitu terdiri dari 5 opsi pilihan jawaban disertai alasan terbuka mengapa siswa memilih opsi tersebut pada bagian A (tipe soal pilihan ganda) dan 9 butir soal yang dijabarkan menjadi 19 poin butir soal uraian pada bagian B (tipe soal uraian). Aspek keterampilan berpikir kritis pada indikator memberikan penjelasan lebih lanjut terdiri dari 5 soal pilihan ganda beralasan pada bagian A.

Analisis data yang dilakukan pada penelitian ini dilakukan dengan mengoreksi jawaban siswa, pemberian skor disesuaikan dengan kriteria yang terdapat pada instrumen penilaian keterampilan berpikir kritis yang digunakan. Pemberian skor dikategorikan menjadi skor 1 dan skor 0 . Skor 1 diperoleh siswa jika siswa mendapat poin 3 atau 2 (menjawab soal pilihan ganda dengan benar), sedangkan skor 0 diperoleh siswa jika siswa mendapat poin 1 atau 0 (salah dalam menjawab soal pilihan ganda). Penentuan persentase pada tiap soal yang diperoleh oleh masing-masing siswa dapat dihitung dengan rumus sebagai berikut.

$$
\text { Nilai Persentase }=\frac{\text { Jumlah siswa yang mendapat skor maksimal }}{\text { Jumlah siswa sampel secara keseluruhan }} \times 100 \%
$$

Tiap-tiap soal dikelompokkan berdasarkan aspek indikator, subindikator, dan subsubindikator keterampilan berpikir kritis siswa. Subindikator keterampilan berpikir kritis siswa pada indikator memberikan penjelasan lebih lanjut terdiri dari 1) mendefinisikan istilah-istilah dan menilai definisi menggunakan kriteria yang sesuai (mempertimbangkan 3 dimensi ; bentuk fungsi dan isi), dan 2) menguraikan asumsi yang tidak dinyatakan. Selanjutnya, ditentukan persentase pada setiap aspek keterampilan berpikir kritis siswa pada tiap indikator, subindikator, dan subsubindikator yang diperoleh oleh masing-masing siswa dan ditentukan tingkat keterampilan berpikir kritis siswa tersebut dengan menggunakan kriteria yang telah diadaptasi dari Karim (2015) yang disajikan dalam Tabel 1.

Tabel 1 Kategori Penentuan Tingkat Keterampilan Berpikir Kritis Siswa

\begin{tabular}{cc}
\hline Persentase & Kategori \\
\hline $0<$ Nilai $\leq 43,75$ & Sangat Rendah \\
$43,75<$ Nilai $\leq 62,50$ & Rendah \\
$62,50<$ Nilai $\leq 71,50$ & Cukup \\
$71,50<$ Nilai $\leq 81,25$ & Tinggi \\
$81,25<$ Nilai $\leq 100,00$ & Sangat Tinggi \\
\hline
\end{tabular}

Sumber: Diadaptasi dari Karim (2015) 


\section{HASIL DAN PEMBAHASAN}

\section{Analisis Hasil Penelitian Keterampilan Berpikir Kritis Siswa dengan Indikator Memberikan Penjelasan Lebih Lanjut pada Materi Hidrokarbon}

Analisis data pada penelitian ini didasarkan pada persentase keterampilan berpikir kritis yang dimiliki siswa pada indikator memberikan penjelasan lebih lanjut dibagi menjadi tiap subindikator dan subsubindikator. Persentase dihitung dari siswa yang memperoleh skor 1 dengan kriteria siswa mampu menjawab dengan benar opsi pilihan pada soal pilihan ganda. Persentase keterampilan berpikir kritis yang dimiliki siswa dalam menjawab soal instrumen pilhan ganda beralasan pada materi hidrokarbon pada indikator memberikan penjelasan lebih lanjut berdasarkan hasil tes disajikan pada Gambar 1.

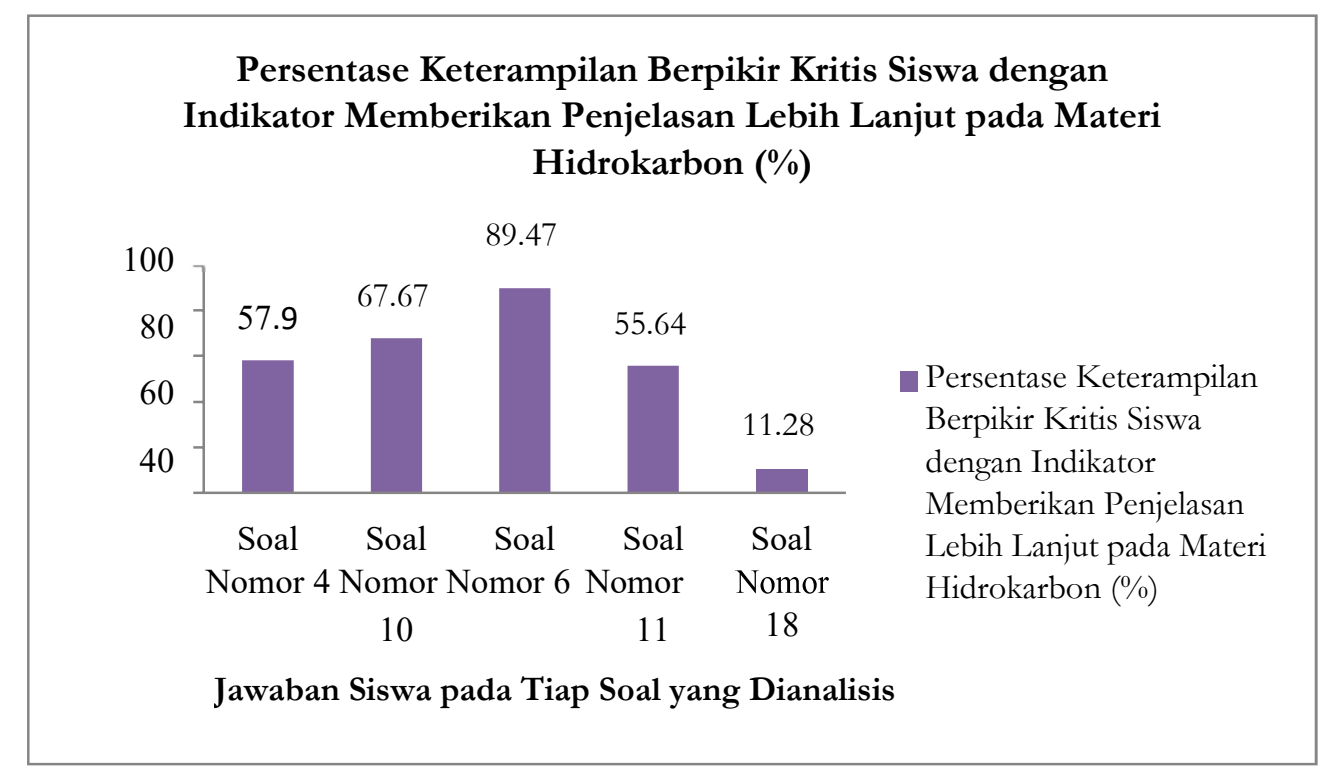

Gambar 1 Grafik Persentase Keterampilan Berpikir Kritis Siswa dengan Indikator Memberikan Penjelasan Lebih Lanjut pada Materi Hidrokarbon

Gambar 1 menunjukkan grafik persentase dari hasil analisis jawaban siswa. Keterangan lebih rinci mengenai persentase keterampilan berpikir kritis yang dimiliki siswa dalam menjawab soal instrumen pilhan ganda beralasan pada materi hidrokarbon pada indikator memberikan penjelasan lebih lanjut berdasarkan hasil tes disajikan pada Tabel 2.

Tabel 2 menunjukkan bahwa persentase keterampilan berpikir kritis yang dimiliki oleh siswa dalam menjawab lima soal tersebut. Memberikan penjelasan lebih lanjut merupakan salah satu indikator yang memiliki tingkat kesukaran yang tinggi. Akan tetapi, terdapat beberapa siswa yang mampu menjawab dengan benar.

\section{Uraian Hasil Jawaban Siswa pada Pokok Bahasan Isomer Senyawa Hidrokarbon}

Keterampilan berpikir kritis siswa pada indikator memberikan penjelasan lebih lanjut dalam menjawab soal dengan pokok bahasan isomer senyawa hidrokarbon termasuk ke dalam kategori rendah. Pokok bahasan ini memiliki indikator soal yaitu setelah diberikan informasi mengenai perbedaan isobutana dan n-butana, siswa mampu menelaah definisi istilah isomer secara lebih mendalam dengan tepat. Berdasarkan indikator soal tersebut, siswa mampu menelaah definisi atau makna dari suatu bentuk istilah atau pernyataan yang terdapat dalam teks yang disajikan. Hal tersebut dibuktikan dengan hasil tes yang dilakukan menunjukkan data sebanyak 77 siswa dengan persentase $57,90 \%$ dari keseluruhan siswa dapat menjawab soal tepat dan kritis sehingga mendapat skor 1 yang dicerminkan dalam soal pilihan ganda beralasan nomor 4. 
4. Isobutana dan n-butana merupakan senyawa yang biasa digunakan sebagai gas propelan (gas pendorong) dalam produk aerosol spray seperti pengharum ruangan, obat nyamuk, obat serangga, dsb. Kedua senyawa tersebut dapat mengalami pembakaran, bereaksi dengan halogen, dan mengalami dehidrogenasi pada suhu tinggi. Namun, meskipun isobutana dan nbutana merupakan senyawa yang berisomer, kedua senyawa tersebut memiliki beberapa karakteristik yang berbeda. Beberapa perbedaan kedua senyawa tersebut disajikan pada tabel berikut.

\begin{tabular}{|l|c|c|}
\multicolumn{1}{|c|}{ Perbedaan } & Isobutana & $n$-butana \\
\hline Titik didih & $-11,72^{\circ} \mathrm{C}$ & $-0,51^{\circ} \mathrm{C}$ \\
\hline Titik leleh & $-159,6^{\circ} \mathrm{C}$ & $-138,36^{\circ} \mathrm{C}$ \\
\hline Densitas uap & $0,00248 \mathrm{~g} / \mathrm{mL}$ & $0,00254 \mathrm{~g} / \mathrm{mL}$ \\
\hline
\end{tabular}

Berdasarkan informasi tersebut, pernyataan berikut yang tepat mengenai isomer adalah...

A. Isomer adalah peristiwa dimana dua senyawa atau lebih memiliki numus moleksl yang sama tetapi cara atom-atomnya berikatan berbeda-beda

B. Senyawa yang berisomer memiliki sifat kimia yang sama, tetapi memiliki rumus struktur dan beberapa sifat fisika yang berbeda

C. Senyawa-senyawa yang berisomer selalu digunakan bersamaan karena memiliki kegunaan yang sama

D. Sifat yang teramati tanpa mengubah zat-zat penyusun dari senyawa yang berisomer selalu sama

E. Sifat yang dapat diamati setelah materi mengalami perubahan kimia dari senyawa yang berisomer selalu berbeda

Alasan:

Gambar 2. Pertanyaan No. 4

Indikator pada soal nomor 4 adalah memberikan penjelasan lebih lanjut mengenai telaah definisi isomer berdasarkan informasi yang diberikan. Berdasarkan keterampilan berpikir kritis yang telah diuraikan dan digabungkan dengan pengetahuan yang telah diperoleh siswa pada materi isomer senyawa hidrokarbon maka hal tersebut dapat digunakan siswa untuk mengidentifikasi kelompok senyawa yang saling berisomer berdasarkan informasi yang disajikan. Terdapat siswa yang memiliki alur berpikir berdasarkan logika yang digabungkan dengan pengetahuan yang telah diperoleh dengan data yang disajikan pada soal. Selain itu, terdapat siswa yang menjawab berdasarkan gambaran struktur kedua isomer tersebut yang digabungkan dengan pengetahuan yang telah diperoleh. 
Tabel 2 Persentase Hasil dari Jawaban Siswa pada Tiap Soal Pilihan Ganda Beralasan

\begin{tabular}{|c|c|c|c|c|}
\hline $\begin{array}{c}\text { Pokok } \\
\text { Bahasan }\end{array}$ & $\begin{array}{c}* \\
\text { Kriteria } \\
\text { Skor } 1\end{array}$ & Kategori & $\begin{array}{c}\text { Subndikator Keterampilan } \\
\text { Berpikir Kritis - } \\
\text { Subsubindikator Keterampilan } \\
\text { Berpikir Kritis }\end{array}$ & $\begin{array}{l}\text { No. } \\
\text { Soal }\end{array}$ \\
\hline $\begin{array}{l}\text { Isomer } \\
\text { senyawa } \\
\text { hidrokarbon }\end{array}$ & $57,90 \%$ & Rendah & $\begin{array}{l}\text { Subindikator: Mendefinisikan } \\
\text { istilah-istilah dan menilai definisi } \\
\text { menggunakan kriteria yang sesuai } \\
\text { (mempertimbangkan } 3 \text { dimensi ; } \\
\text { bentuk fungsi dan isi) } \\
\text { Subsubindikator: Mendefinisikan } \\
\text { bentuk (sinonim, klasifikasi, } \\
\text { rentang, ekspresi yang sama, } \\
\text { operasional, serta contoh dan } \\
\text { bukan contoh) }\end{array}$ & $\begin{array}{c}4 \\
(\mathrm{PG})\end{array}$ \\
\hline $\begin{array}{l}\text { Kegunaan } \\
\text { senyawa } \\
\text { hidrokarbon }\end{array}$ & $67,67 \%$ & Cukup & $\begin{array}{l}\text { Subindikator: Mendefinisikan } \\
\text { istilah-istilah dan menilai definisi } \\
\text { menggunakan kriteria yang sesuai } \\
\text { (mempertimbangkan } 3 \text { dimensi ; } \\
\text { bentuk fungsi dan isi) } \\
\text { Subsubindikator: Mendefinisikan } \\
\text { fungsi }\end{array}$ & $\begin{array}{c}10 \\
(\mathrm{PG})\end{array}$ \\
\hline $\begin{array}{l}\text { Sifat fisika } \\
\text { dan sifat } \\
\text { kimia } \\
\text { senyawa } \\
\text { hidrokarbon } \\
\text { : sifat fisika } \\
\text { senyawa } \\
\text { hidrokarbon }\end{array}$ & $89,47 \%$ & $\begin{array}{l}\text { Sangat } \\
\text { Tinggi }\end{array}$ & $\begin{array}{l}\text { Subindikator: Mendefinisikan } \\
\text { istilah-istilah dan menilai definisi } \\
\text { menggunakan kriteria yang sesuai } \\
\text { (mempertimbangkan } 3 \text { dimensi ; } \\
\text { bentuk fungsi dan isi) } \\
\text { Subsubindikator: Mengidentifikasi } \\
\text { dan menangani ketidakjelasan }\end{array}$ & $\begin{array}{c}6 \\
(\mathrm{PG})\end{array}$ \\
\hline \multirow{3}{*}{$\begin{array}{l}\text { Sifat fisika dan } \\
\text { sifat kimia } \\
\text { senyawa } \\
\text { hidrokarbon : } \\
\text { reaksi } \\
\text { pembakaran } \\
\text { senyawa } \\
\text { hidrokarbon } \\
\text { Tata nama } \\
\text { senyawa } \\
\text { hidrokarbon }\end{array}$} & $55,64 \%$ & Rendah & $\begin{array}{l}\text { Subindikator: } \\
\text { Menguraikan asumsi yang tidak } \\
\text { dinyatakan } \\
\text { Subsubindikator: } \\
\text { Tidak memiliki perasaan ragu atau } \\
\text { takut salah }\end{array}$ & $\begin{array}{c}4 \\
(\mathrm{PG})\end{array}$ \\
\hline & $11,28 \%$ & $\begin{array}{l}\text { Sangat } \\
\text { Rendah }\end{array}$ & $\begin{array}{l}\text { Subindikator: } \\
\text { Menguraikan asumsi yang tidak } \\
\text { dinyatakan } \\
\text { Subsubindikator: } \\
\text { Memperkirakan dan menggunakan } \\
\text { asumsi }\end{array}$ & $\begin{array}{r}10 \\
(\mathrm{PG})\end{array}$ \\
\hline & \multicolumn{3}{|c|}{$\begin{array}{l}\% \text { rata-rata siswa yang mendapat kriteria skor } 1 \text { pada indikator } \\
\text { memberikan penjelasan lebih lanjut }\end{array}$} & $56,40 \%$ \\
\hline
\end{tabular}

Catatan :

*Kriteria skor 1): Opsi pilihan ganda benar (Skor: 3 atau 2 pada lima soal bagian A dengan indikator memberikan penjelasan lebih lanjut) 


\section{Uraian Hasil Jawaban Siswa pada Pokok Bahasan Kegunaan Senyawa Hidrokarbon}

Keterampilan berpikir kritis siswa pada indikator memberikan penjelasan lebih lanjut dalam menjawab soal dengan pokok bahasan kegunaan senyawa hidrokarbon termasuk ke dalam kategori cukup. Pokok bahasan ini memiliki indikator soal yaitu setelah disajikan artikel mengenai kanola dan minyak kanola, siswa mampu menjelaskan fungsi dari penambahan n-heksana dalam ekstraksi minyak kanola dengan tepat sesuai artikel yang disajikan. Berdasarkan indikator soal tersebut, siswa mampu menjelaskan fungsi dari pernyataan yang terdapat dalam teks yang disajikan. Hal tersebut dibuktikan dengan hasil tes yang dilakukan menunjukkan data sebanyak 90 siswa dengan persentase $67,67 \%$ dari keseluruhan siswa dapat menjawab soal tepat dan kritis sehingga mendapat skor 1 yang dicerminkan dalam soal pilihan ganda beralasan nomor 10 .

10. Bacalah dengan seksama artikel berikut!

Kanola merupakan tanaman dengan

tinggi satu hingga dua meter yang memiliki kelopak bunga berwarna kuning dengan bentuk menyilang. Biii kanola mengandung sekitar $43 \%$ minyak, sehingga apabila biji tersebut dihancurkan dan diolah maka akan

dihasillkan minyak sayur. Dalam industri, ekstraksi minyak kanola dari bijinya dilaksukan melalui beberapa tahap yang meliputi pembersihan biji, pengelupasan kılit biji, pemasakan biji, penghancuran biji dengan cara ditekan oleh alat khusus, ekstraksi dengan pelarut $n$-heksana, pemisahan minyak dengan $n$-heksana, dan pengolahan minyak lebih lanjut. Setelah selunuh tahap dilalui, maka akan dihasillkan minyak kanola yang siap digunakan.

(Sumber: https://canolagrowers.com/np-content/uploads/2014/11/Canola_Glossy 2010_1.pdf

Fungsi dari penambahan $n$-heksana dalam proses ekstraksi minyak kanola sesuai dengan artikel tersebut adalah ....

A. Memisahkan minyak kanola dan senyawa nonpolar lainnya dengan memanfaatkan teori kelarutan

B. Bereaksi dengan minyak kanola membentuk senyawa lain yang mudah dipisahkan

C. Mengikat minyak kanola yang terdapat dalam biji yang telah dihancurkan melalui proses substitusi

D. Menggumpalkan senyawa-senyawa selain minyak kanola agar dapat dilakukan penyaringan

E. Sebagai pengikat dari minyak kanola karena keduanya merupakan senyawa alkana Alasan:

Gambar 3. Pertanyaan No. 10

Indikator pada soal nomor 10 adalah memberikan penjelasan lebih lanjut tentang kegunaan nheksana dalam artikel senyawa hidrokarbon sesuai dengan informasi yang disajikan. Siswa menjawab soal yang menanyakan fungsi dari penambahan n-heksana dalam ekstraksi minyak kanola. Siswa menghubungkan sifat fisika n-heksana yaitu kelarutannya dengan prinsip like dissolves like. Kemudian, siswa mampu menjelaskan fungsi n-heksana dalam ekstraksi minyak kanola dengan tepat dan kritis sesuai prinsip like dissolves like. 


\section{Uraian Hasil Jawaban Siswa pada Pokok Bahasan Sifat Fisika dan Sifat Kimia Senyawa Hidrokarbon: Sifat Fisika Senyawa Hidrokarbon}

Keterampilan berpikir kritis siswa pada indikator memberikan penjelasan lebih lanjut dalam menjawab soal dengan pokok bahasan sifat fisika dan sifat kimia senyawa hidrokarbon: sifat fisika senyawa hidrokarbon termasuk ke dalam kategori sangat tinggi. Pokok bahasan ini memiliki indikator soal yaitu setelah diberikan pernyataan mengenai perbedaan penafsiran prosedur percobaan kelarutan senyawa hidrokarbon dalam sejumlah pelarut yang kurang jelas, siswa mampu memberikan tanggapan terhadap ketidakjelasan prosedur percobaan tersebut dengan kritis dan tepat. Berdasarkan indikator soal tersebut, siswa mampu mengidentifikasi dan menangani ketidakjelasan yang terdapat dalam teks yang disajikan. Hal tersebut dibuktikan dengan hasil tes yang dilakukan menunjukkan data sebanyak 119 siswa dengan persentase 89,47\% dari keseluruhan siswa dapat menjawab soal tepat dan kritis sehingga mendapat skor 1 yang dicerminkan dalam soal pilihan ganda beralasan nomor 6 .

6. Lina dan Ria akan melakukan percobaan uji kelanutan senyawa $n$-heksana (sampel). Setelah membaca prosedur percobaan, mereka menemukan bagian terpenting dari prosedur yang akan dilakukan yaitu menambahkan beberapa tetes sampel ke dalam $2 \mathrm{~mL}$ pelarut yang berbeda-beda. Namun, ternyata Lina dan Ria memiliki cara pandang yang berbeda dalam menafsirkan prosedur tersebut. Lina menambahkan beberapa tetes sampel ke dalam beberapa jenis pelanut pada tabung reaksi yang sama dengan total volume $2 \mathrm{~mL}$, sedangkan Ria menambahkan beberapa tetes sampel ke dalam beberapa jenis pelarut dengan volume 2 $\mathrm{mL}$ pada tabung reaksi yang berbeda. Akibatnya, hasil percobaan yang diperoleh pun berbeda. Tanggapan yang tepat mengenai perbedaan penafsiran akibat ketidakjelasan prosecur tersebut adalah...

A. Hasil percobaan Lina lebih tepat karena sampel dengan volume yang sama berada pada satu tabung yang sama pula sehingga uji kelanutan yang didapatkan akurat

B. Prosedur yang dilakukan Lina kurang tepat karena penambahan sampel ke dalam beberapa pelant pada tabung reaksi yang sama memudahkan pengotor masuk ke dalam lanutan

C. Percobaan yang dilakukan Ria kurang tepat karena penambahan sampel ke dalam beberapa pelanut pada tabung yang berbeda tidak dapat mengukur kelarutan sampel

D. Hasil percobaan Ria lebih akurat karena penambahan sampel ke dalam beberapa pelanut pada tabung yang berbeda mempermudah pengamatan kelanutan sampel

E. Penafsiran Lina dan Ria tersebut benar, perbedaan hasil percobaan sudah biasa terjadi pada suatu percoban, sehingga mereka hanya perlu menganalisis alasan terjadinya perbedaan tersebut

Alasan:

Gambar 4. Pertanyaan No. 6

Indikator pada soal nomor 6 adalah memberikan penjelasan lebih lanjut mengenai ketidakjelasan penafsiran prosedur uji kelarutan senyawa hidrokarbon. Siswa diminta untuk memberikan tanggapan terhadap ketidakjelasan prosedur yang dilakukan oleh dua orang yang berbeda dalam melakukan sebuah percobaan. Siswa mampu menjawab dengan tepat dan kritis dengan memerhatikan kedua langkah percobaan yang berbeda seperti yang terdapat pada soal yang disajikan, siswa melihat keakuratkan dan dampak yang diperoleh dari dua penafsiran prosedur tersebut.

\section{Uraian Hasil Jawaban Siswa pada Pokok Bahasan Sifat Fisika dan Sifat Kimia Senyawa} Hidrokarbon: Reaksi Pembakaran Senyawa Hidrokarbon

Keterampilan berpikir kritis siswa pada indikator memberikan penjelasan lebih lanjut dalam menjawab soal dengan pokok bahasan sifat fisika dan sifat kimia senyawa hidrokarbon: reaksi 
pembakaran senyawa hidrokarbon termasuk ke dalam kategori rendah. Pokok bahasan ini memiliki indikator soal yaitu siswa mampu mengidentifikasi persamaan reaksi pembakaran gas dalam LPG yang secara implisit terdapat dalam informasi yang disajikan dengan ketepatan 100\% apabila diberikan informasi komponen gas dalam LPG dan perbandingannya. Berdasarkan indikator soal tersebut, siswa mampu menjelaskan atau menguraikan asumsi yang tidak dinyatakan secara langsung (implisit) pada teks yang disajikan tanpa memiliki perasaan ragu atau takut salah. Hal tersebut dibuktikan dengan hasil tes yang dilakukan menunjukkan data sebanyak 74 siswa dengan persentase 55,64\% dari keseluruhan siswa dapat menjawab soal tepat dan kritis sehingga mendapat skor 1 yang dicerminkan dalam soal pilihan ganda beralasan nomor 11 .

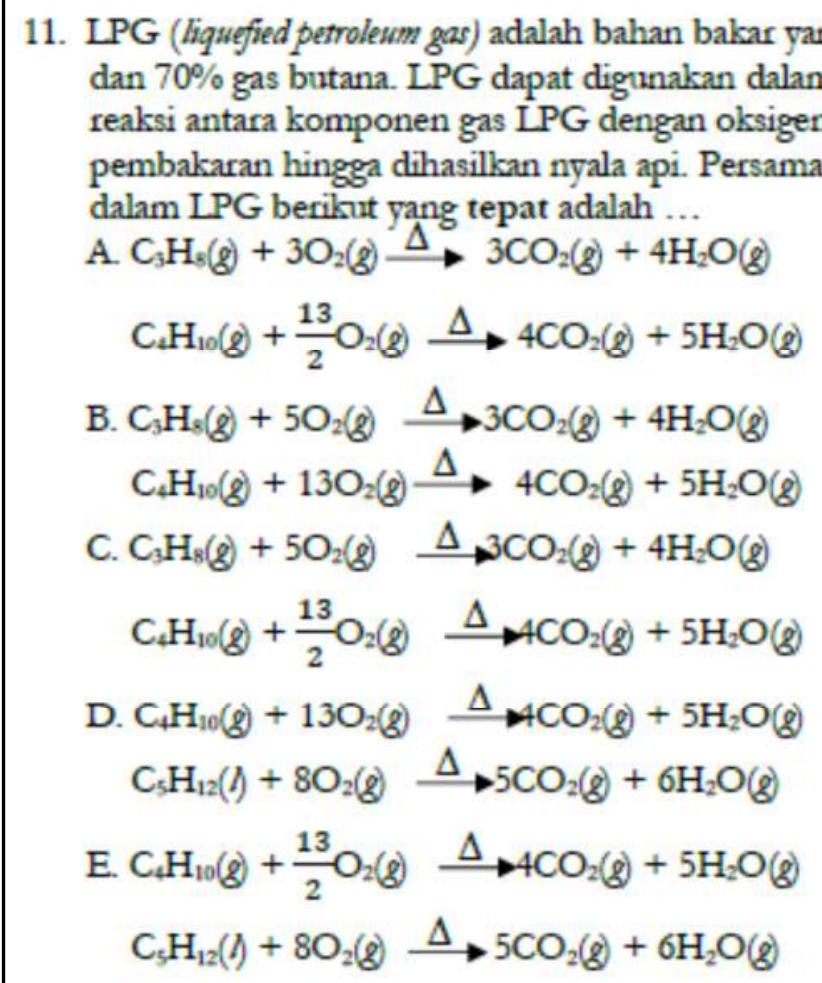

Alasan:

Gambar 5. Pertanyaan No. 11

Indikator pada soal nomor 11 adalah memberikan penjelasan lebih lanjut berdasarkan informasi reaksi pembakaran gas dalam LPG secara tersirat yang telah disajikan. Siswa mampu berpikir kritis dengan menggunakan informasi yang disajikan untuk menuliskan persamaan reaksi pembakaran komponen gas LPG. Setelah menentukan persamaan reaksi pembakaran yang terjadi, siswa melakukan penyetaraan koefisien sehingga diperoleh reaksi pembakaran gas dalam LPG yang setara.

\section{Uraian Hasil Jawaban Siswa pada Pokok Bahasan Tata Nama Senyawa Hidrokarbon}

Keterampilan berpikir kritis siswa pada indikator memberikan penjelasan lebih lanjut dalam menjawab soal dengan pokok bahasan tata nama senyawa hidrokarbon termasuk ke dalam kategori sangat rendah. Terdapat sebagian siswa belum dapat menjawab dengan tepat dan kritis dengan jumlah yang cukup banyak pada tingkatan indikator dengan taraf kesukaran yang tinggi. Pokok bahasan ini memiliki indikator soal yaitu siswa mampu memperkirakan struktur dan rumus umum polipropilena yang secara tersirat terdapat dalam artikel yang diberikan dengan ketepatan 100\% apabila diberikan artikel mengenai polipropilena. Berdasarkan indikator soal tersebut, siswa mampu menggunakan asumsi untuk menyelesaikan suatu permasalahan lain yang hampir sama. Hal tersebut dibuktikan dengan hasil tes yang dilakukan menunjukkan data sebanyak 15 siswa dengan 
persentase $11,28 \%$ dari keseluruhan siswa dapat menjawab soal tepat dan kritis sehingga mendapat skor 1 yang dicerminkan dalam soal pilihan ganda beralasan nomor 18.

18. Bacalah dengan cermat cuplikan informasi berikut!

\section{Polipropilena merupakan} senyawa alkena yang banyak digunakan dalam kehidupan seharihari. Salah satu pemanfaatan dari polipropilena adalah sebagai bahan baku pembuatan uang kertas.

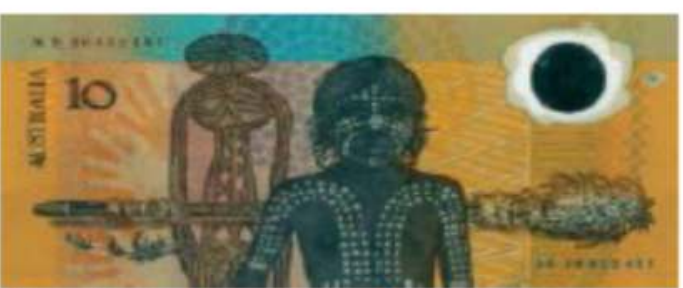

Pada tahun 1988, uang kertas Australia dicetak pada polipropilena agar aman dan memiliki daya tahan yang tinggi. Polipropilena sendiri dibuat melalui polimerisasi adisi senyawa propilena.

(Sumber: Burde, J. dan Overby, J. 2018. Chemistry Atoms First. New York: McGrawHill.)

Berdasarkan informasi tersebut, struktur polipropilena dan rumus umum poliprop: tepat adalah ...

A.<smiles>CCC(C)C(C)C(C)C(C)C(C)C(C)C(C)C(C)C(C)C</smiles>

B.<smiles>CC=C(C)C=CC(C)=CC</smiles><smiles>CCCCC(C)C=CC(C)C</smiles>

C.

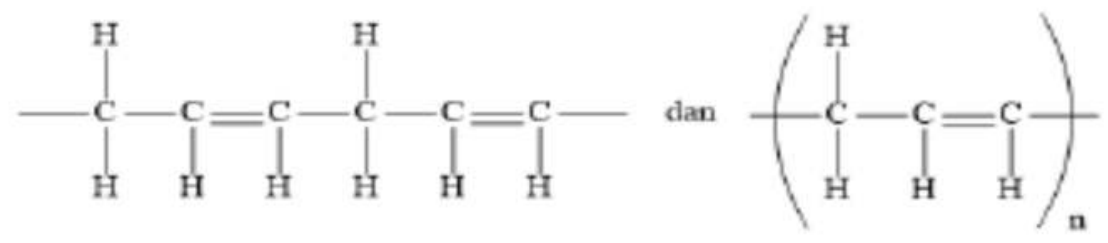

D.

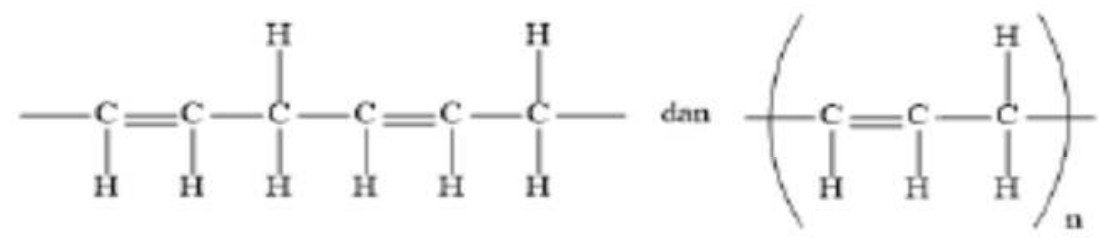

E.

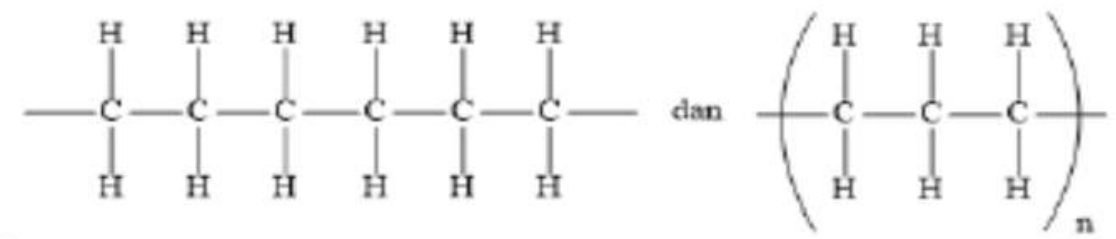

Alasiun.

Gambar 6. Pertanyaan No. 18 
Indikator pada soal nomor 18 adalah memberikan penjelasan lebih lanjut mengenai perkiraan struktur dan rumus umum polipropilena secara tersirat dalam informasi yang diberikan. Namun, beberapa siswa mampu menjawab dengan benar dan kritis mengenai soal yang disajikan. Artikel yang disajikan dalam soal mengenai pemanfaatan dan pembuatan senyawa polipropilena yang menyebutkan bahwa pembuatan senyawa polipropilena yaitu melalui polimerisasi adisi senyawa propilena. Berdasarkan informasi tersebut, siswa menuliskan rumus propilena kemudian dihubungkan lebih lanjut dengan reaksi polimerisasi adisi senyawa propilena sehingga siswa mampu menemukan struktur dan rumus umum yang tepat dari senyawa polipropilena.

\section{Keterampilan Berpikir Kritis Siswa Berdasarkan Analisis}

Berdasarkan uraian di atas dan data yang terdapat pada Tabel 2 yang disajikan menunjukkan persentase keterampilan berpikir kritis yang dimiliki siswa berbeda-beda. Alasan dari pemilihan opsi jawaban yang dijelaskan oleh siswa untuk menjawab soal tes dengan benar tidak hanya melalui satu alasan yang sama, masing-masing siswa memiliki alur berpikir yang berbeda-beda dalam memberikan penjelasan lebih lanjut untuk menjawab soal tes keterampilan berpikir kritis yang diujikan. Setiap siswa memiliki keterampilan berpikir kritis yang berbeda-beda meskipun berasal dari sekolah yang sama karena keterampilan tersebut dipengaruhi oleh materi dan aspek indikator sehingga tidak semua siswa memiliki tingkat keterampilan yang sama. Menurut Kuswana dalam Kartimi dkk (2012), keterampilan berpikir kritis berhubungan dengan tingkat kecerdasan. Keterampilan berpikir kritis tidak serta-merta diperoleh siswa, diperlukan adanya penggabungan antara kecerdasan dan reatifitas siswa untuk memperoleh keterampilan ini. Menurut Penner dalam Kartimi dkk (2012), diperlukan adanya latihan dalam mengembangkan keterampilan berpikir kritis dan motorik. Keterampilan berpikir kritis memang memerlukan latihan dan bimbingan supaya keterampilan tersebut dapat meningkat.

\section{KESIMPULAN}

Hasil penelitian menunjukkan bahwa keterampilan berpikir kritis dengan indikator memberikan penjelasan lebih lanjut pada materi hidrokarbon yaitu a) sejumlah $57,90 \%$ siswa mampu menjawab dengan benar dan mendapat skor 1 dalam menjawab soal pilihan ganda dengan pokok bahasan isomer senyawa hidrokarbon dan termasuk ke dalam kategori rendah, b) sejumlah 67,67\% siswa mampu menjawab dengan benar dan mendapat skor 1 dalam menjawab soal pilihan ganda dengan pokok bahasan kegunaan senyawa hidrokarbon dan termasuk ke dalam kategori cukup, c) sejumlah 89,47\% siswa mampu menjawab dengan benar dan mendapat skor 1 dalam menjawab soal pilihan ganda dengan pokok bahasan sifat fisika dan sifat kimia senyawa hidrokarbon : sifat fisika senyawa hidrokarbon dan termasuk ke dalam kategori sangat tinggi, d) sejumlah 55,64\% siswa mampu menjawab dengan benar dan mendapat skor 1 dalam menjawab soal pilihan ganda dengan pokok bahasan sifat fisika dan sifat kimia senyawa hidrokarbon : reaksi pembakaran senyawa hidrokarbon dan termasuk ke dalam kategori rendah, dan e) sejumlah 11,28\% siswa mampu menjawab dengan benar dan mendapat skor 1 dalam menjawab soal pilihan ganda dengan pokok bahasan tata nama senyawa hidrokarbon termasuk ke dalam kategori sangat rendah.

\section{DAFTAR RUJUKAN}

Arends, R. I. 2012. Learning to Teach Ninth Edition. New York: The Mc Graw- Hill Companies, Inc.

Bao, L., Hogg, K. \& Zollman, D. 2002. Model Analysis of Fine Structures of Student Models: An Example with Newton's Third Law. American Association of Physics Teachers, 70(7): 766-778.

Ennis, R. H. 2011. The Nature of Critical Thinking: An Outline of Critical Thinking Dispositions and Abilities, (Online), http://faculty.education.illinois.edu/rhennis/documents/TheNatureofCritic alThinking_51711_000.pdf), diakses 14 Januari 2019. 
Karim, N. 2015. Kemampuan Berpikir Kritis Siswa dalam Pembelajaran Matematika dengan Menggunakan Model Jucama di Sekolah Menengah Pertama. Jurnal Pendidikan Matematika, 3(1). (Online),

(https://www.researchgate.net/publication/325246731_Analisis_Kemampuan_Ber pikir_Kritis_Siswa_SMP/download), diakses 19 Maret 2019.

Kartimi, L. \& Permanasari, A. 2012. Pengembangan Alat Ukur Berpikir Kritis pada Konsep Senyawa Hidrokarbon untuk Siswa SMA di Kabupaten Kuningan. Jurnal Pendidikan MIPA, 13 (1). (Online), (http://jurnal.fkip.unila.ac.id/index.php/JPM/article/view/ 397/154), diakses 14 Januari 2019.

Lai, E.R. (2011). Critical Thinking: A Literature Review. London: PEARSON.

OECD. 2016. Programme for International Student Assessment (PISA) Result from PISA 2015. (Online), (https://www.oecd.org/pisa/PISA-2015- Indonesia.pdf), diakses pada 29 April 2019.

Puspita, I., Kaniawati, L., \& Suwarma, I.R. 2017. Analysis of Critical Thinking Skills on The Topic Static Fluid. Journal of Physics: Conf. Series 895 (2017) 012100.

Rodliyah, E. A. 2018. Pengembangan Instrumen Penilaian Keterampilan Berpikir Kritis untuk Peserta Didik SMA pada Materi Hidrokarbon. Skripsi. Malang: Universitas Negeri Malang.

Santika, A.R., Purwianingsih, W., \& Nuraeni, E. 2018. Analysis of Students Critical Thinking Skills in Socio-Scientific Issues of Biodiversity Subject. Journal of Physics: Conf. Series 1013 (2018) 012004. 